\title{
A Synthetic Creatinine Receptor: Imprinting of a Lewis-Acidic Zinc(II)cyclen Binding Site to Shape its Molecular Recognition Selectivity
}

\author{
Michael Subat, ${ }^{1}$ A. S. Borovik ${ }^{2}$ and Burkhard König ${ }^{1}$ *
}

\section{SUPPORTING INFORMATION}

Binding isotherms for creatinine and thymine fitted to

Langmuir equation $\quad$ S-2

Details of X-ray structure determination zinc(II)cyclen-creatinine $\quad$ S-4

Potentiometric titrations of zinc(II)cyclen, creatinine and thymine S-5

$\begin{array}{lr}\text { Experimental details of HPLC analyses } & \text { S-8 }\end{array}$

$\begin{array}{ll}\text { IR spectra of polymers } & \text { S-9 }\end{array}$

UV binding assay for flavin absorption to polymers $\quad$ S-12

$\begin{array}{lr}\text { Materials and Techniques } & \text { S-15 }\end{array}$

$\begin{array}{ll}\text { Synthesis } & \text { S-15 }\end{array}$

$\begin{array}{ll}\text { Binding studies } & \text { S-21 }\end{array}$ 
Binding isotherms for creatinine and thymine fitted to Langmuir equation

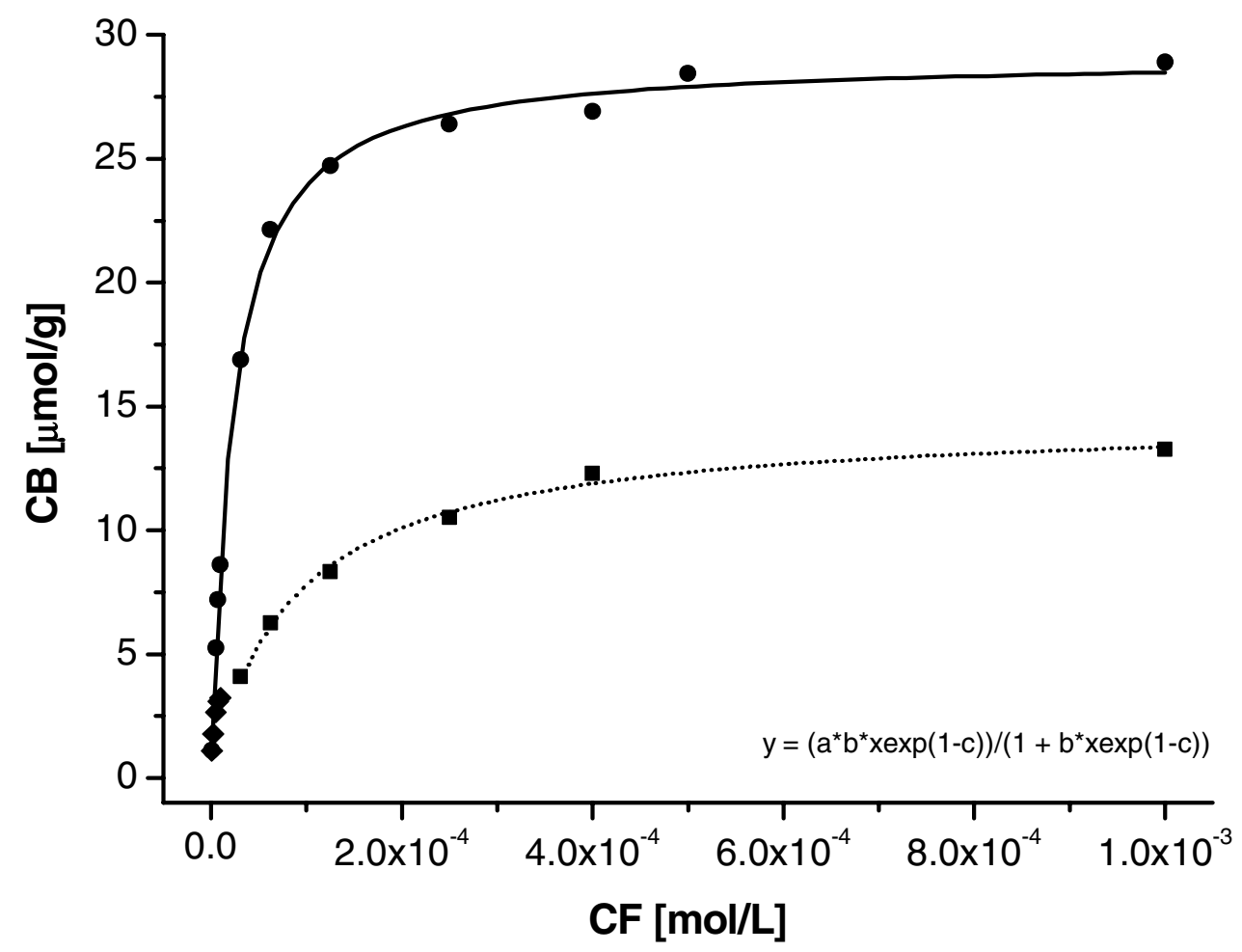

Figure S-1. Creatinine $(\bullet,-)$ ) and thymine $(\bullet$ and $\boldsymbol{\square}, \cdots \cdot)$ binding to 11-Zn-8-B in aqueous buffer fitted to a Langmuir isotherm. Parameters for creatinine (-): $a=29 ; b=6 \times 10^{4}$, $c=-0.03 ; R=0.998$. Parameters for thymine $(\cdots \cdots)$ : $\left(\mathrm{CF}<10^{-5} \mathrm{~mol} / \mathrm{L}\right) a=4 ; b=4 \times 10^{5}$, $c=-0.02 ; R=0.998 .\left(\mathrm{CF}>10^{-5} \mathrm{~mol} / \mathrm{L}\right) a=14 ; b=8 \times 10^{3}, c=0.03 ; R=0.995$. MIP 11-Zn-8B with a lower overall binding capacity was used for isotherm determination.

$\begin{array}{cc}\begin{array}{c}\text { Conc. creatinine } \\ \text { [mol/L] }\end{array} & \mathrm{CB} \text { in }[\mu \mathrm{mo} \\ & \\ & \\ 1,000 \mathrm{E}-03 & 28,88 \\ 5,000 \mathrm{E}-04 & 28,44 \\ 4,000 \mathrm{E}-04 & 26,90 \\ 2,500 \mathrm{E}-04 & 26,38 \\ 1,250 \mathrm{E}-04 & 24,71 \\ 6,250 \mathrm{E}-05 & 22,15 \\ 3,125 \mathrm{E}-05 & 16,89 \\ 1,000 \mathrm{E}-05 & 8,60 \\ 7,500 \mathrm{E}-06 & 7,20 \\ 5,000 \mathrm{E}-06 & 5,25 \\ 1,000 \mathrm{E}-06 & 1,12 \\ & \end{array}$


S-3

$\begin{array}{cr}\begin{array}{c}\text { Conc. thymine } \\ \text { [mol/L] }\end{array} & \text { CB in }[\mu \mathrm{m} \\ & \\ & \\ 1,000 \mathrm{E}-03 & 13,27 \\ 5,000 \mathrm{E}-04 & 13,05 \\ 4,000 \mathrm{E}-04 & 12,30 \\ 2,500 \mathrm{E}-04 & 10,50 \\ 1,250 \mathrm{E}-04 & 8,33 \\ 6,250 \mathrm{E}-05 & 6,26 \\ 3,125 \mathrm{E}-05 & 4,10 \\ 1,000 \mathrm{E}-05 & 3,24 \\ 7,500 \mathrm{E}-06 & 3,10 \\ 5,000 \mathrm{E}-06 & 2,65 \\ 2,000 \mathrm{E}-06 & 1,78 \\ 1,000 \mathrm{E}-06 & 1,10\end{array}$




\section{Details of X-ray structure determination zinc(II)cyclen-creatinine}

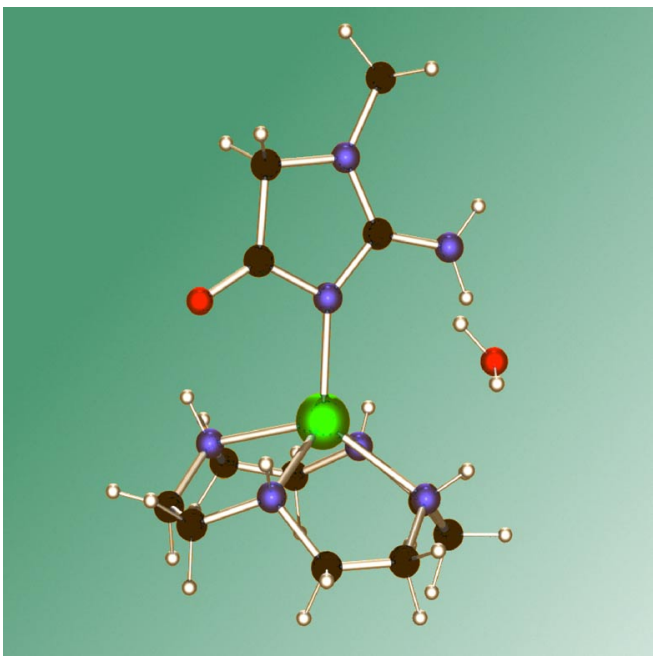

Figure S-2. Structure of zinc(II)cyclen-creatinine in the crystal.

$\mathrm{C}_{12} \mathrm{H}_{27} \mathrm{~N}_{7} \mathrm{OZn}, 2 \cdot \mathrm{ClO}_{4}, \mathrm{H}_{2} \mathrm{O} ; \mathrm{M}=574.59 \mathrm{~g} / \mathrm{mol}$, orthorhombic, space group Pbca, $\mathrm{a}=12.4683$ (7) $\AA, \alpha=90^{\circ}, \mathrm{b}=29.6664$ (15) $\AA, \beta=90^{\circ}, \mathrm{c}=12.4080$ (5) $\AA, \gamma=90^{\circ}$, $\mathrm{V}=4.5896 \mathrm{~nm}^{3}, \mathrm{Z}=8, D_{\mathrm{x}}=1.663 \mathrm{Mg} / \mathrm{m}^{3}, \lambda\left(\mathrm{Mo}_{\mathrm{\alpha}}\right)=71.073 \mathrm{pm}, \mu=1.368 \mathrm{~mm}^{-1}$, $\mathrm{F}(000)=2380, \mathrm{~T}=297$ (2) $\mathrm{K}$. A colorless, flat crystal with the dimensions $0.48 \times 0.45 \times$ $0.05 \mathrm{~mm}$ was used, to collect on a STOE-IPDS diffractometer an overall number of 35813 reflections (4147 independent reflections, $\mathrm{R}_{\text {int }}=0.0538$ ) from $2.14^{\circ}$ to $25.30^{\circ}$.

The structure was solved by direct methods (SIR97) ${ }^{1}$ and the $F^{2}$-value was optimized with the program SHELXL- $-97^{2}$ for all non hydrogen atoms. The position of the hydrogen atoms was calculated. The final $\omega R\left(F^{2}\right)$-value for all reflections was $0.1386 ; R(F)=0.0555, \mathrm{~S}=1.063$, $\max . \Delta \rho=525 \mathrm{e} \cdot \mathrm{nm}^{-3}$.

\footnotetext{
${ }^{1}$ Altomare, A.; Cascarano, G.; Giacovazzo, C.; Guagliardi, A. J. Appl. Cryst. 1993, 26, 343-350.

${ }^{2}$ Sheldrick, G. M. Programm für Kristallstrukturverfeinerung, Universität Göttingen, 1997.
} 


\section{Potentiometric titrations of zinc(II)cyclen and creatinine}

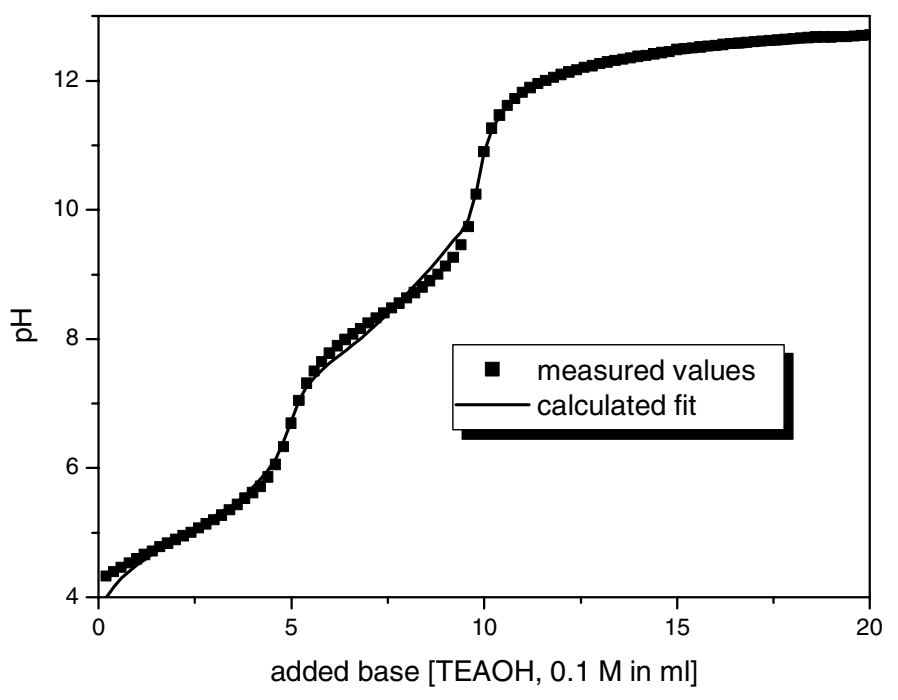

Figure S-3. Potentiometric pH titration of creatinine-hydrochloride and zinc(II)cyclen.

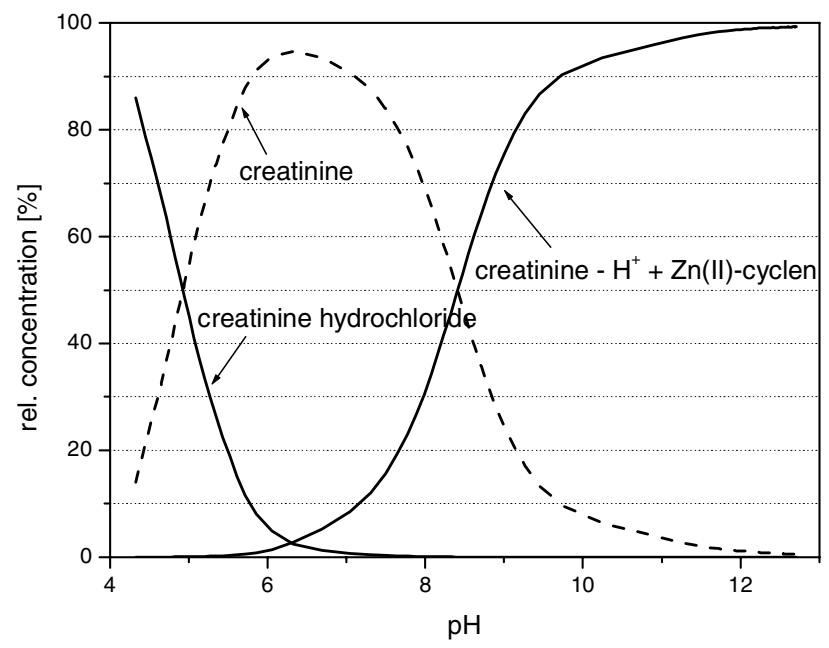

Figure S-4. Species distribution plot of creatinine-hydrochloride and zinc(II)cyclen. 

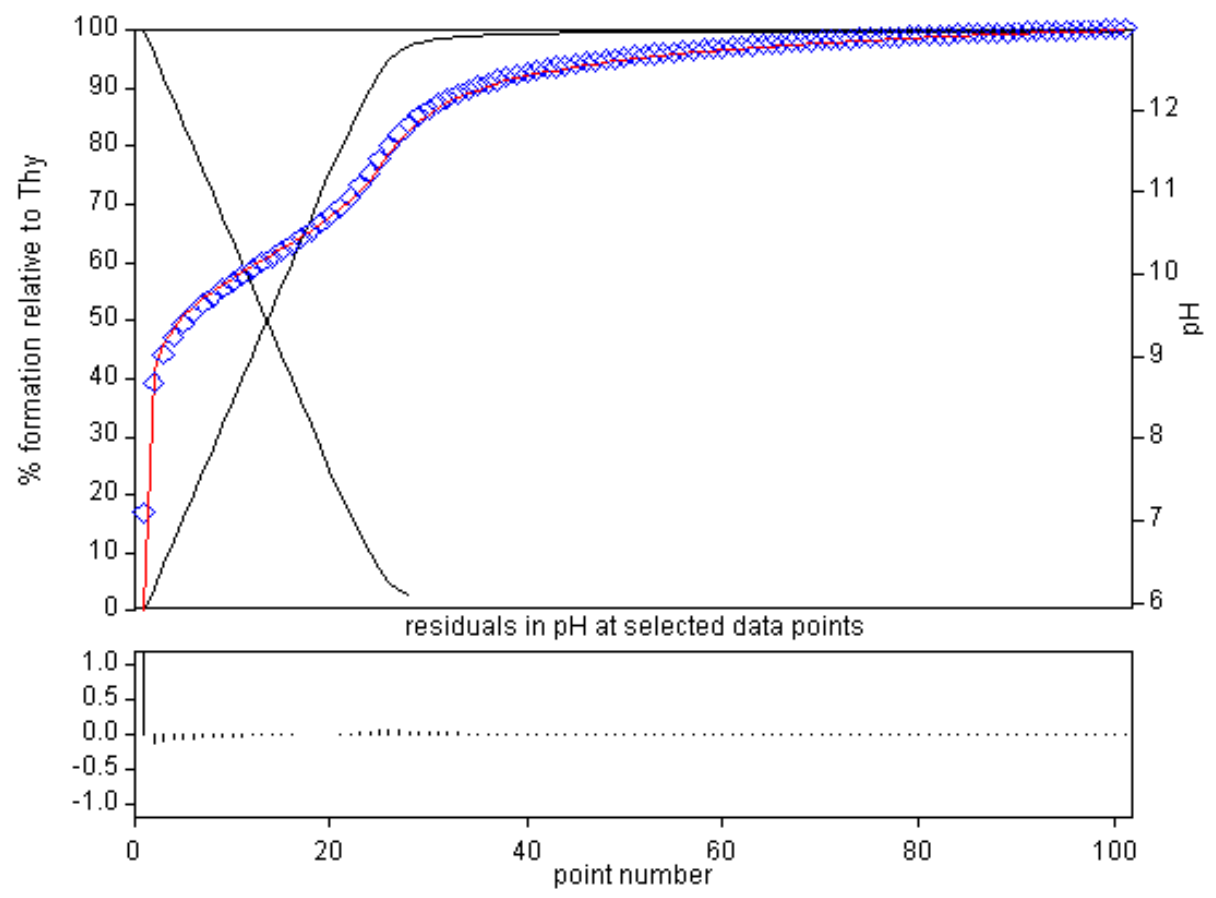

Figure S-5. Potentiometric $\mathrm{pH}$ titration of thymine.

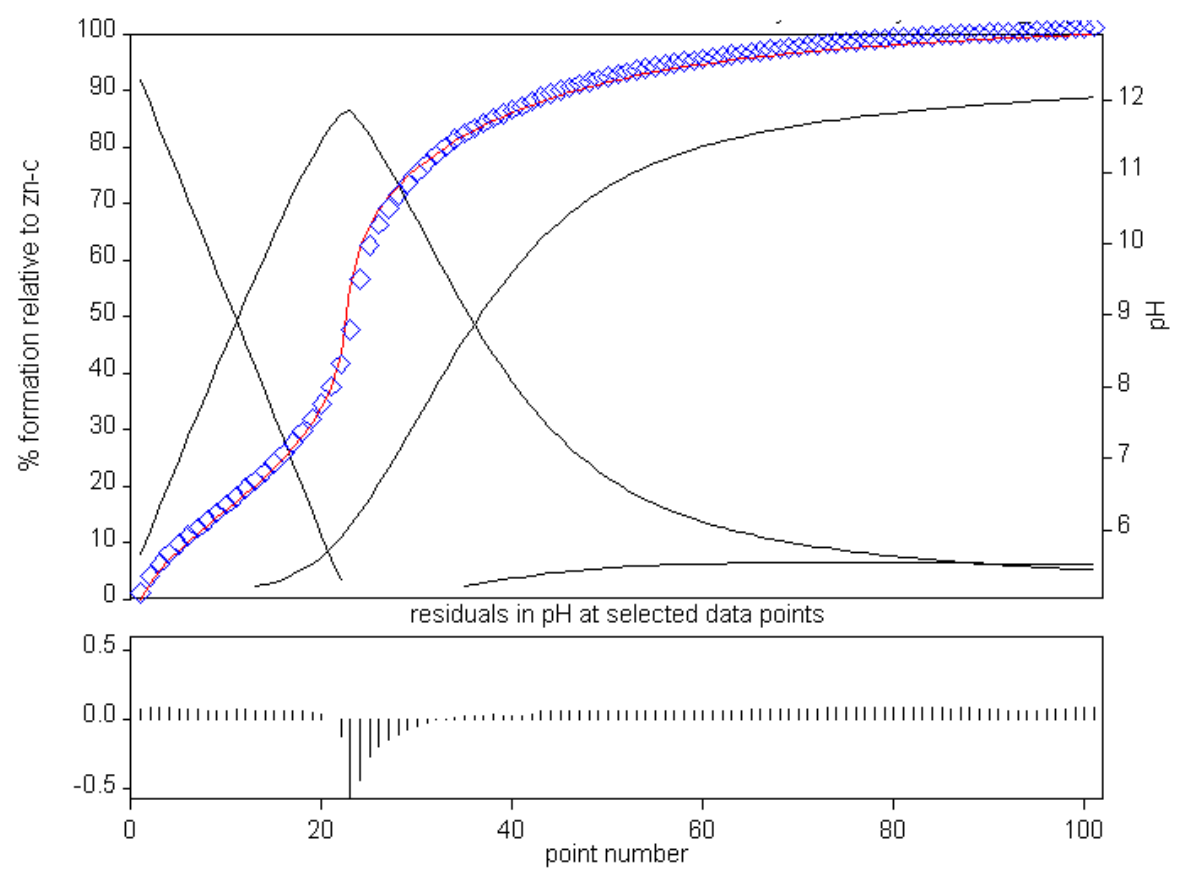

Figure S-6. Potentiometric $\mathrm{pH}$ titration of thymine and zinc(II)cyclen. 
$\mathrm{p} K_{\mathrm{a}}$-values for creatinine-hydrochloride and thymine in homogeneous solution:

creatinine-hydrochloride: $\quad \mathrm{p} K_{\mathrm{a}}=4.95$ and 13.15

thymine: $\quad \mathrm{p} K_{\mathrm{a}}=10.2$

Binding constants for creatinine and thymine at $\mathrm{pH} 9$ :

creatinine: $K=1.97 \times 10^{4} \mathrm{~L} / \mathrm{mol}$

thymine: $K=6.74 \times 10^{5} \mathrm{~L} / \mathrm{mol}$

ratio: creatinine to thymine $1: 34$

Potentiometric titrations: Potentiometric $\mathrm{pH}$ titrations were performed with a computer controlled pH-meter (pH 3000, WTW) and dosimat (dosimat 665, Metrohm). For all titrations $0.1 \mathrm{M}$ perchloric acid and $0.1 \mathrm{M}$ tetraethylammonium hydroxide $(\mathrm{TEAOH})$ in water containing tetraethylammonium perchlorate to maintain an ionic strength of $I=0.1$ were used. TEAOH solutions were calibrated with mono sodium phthalate. A titration of perchloric acid with TEAOH solution was used for calibration and to determine $\log K_{\mathrm{w}}$. All measurements were performed at $25^{\circ} \mathrm{C}$. For determination of $\mathrm{p} K_{\mathrm{a}}$ values and affinity constants the program Hyperquad 2000 was used. $^{3}$

\footnotetext{
${ }^{3}$ Gans, P.; Sabatini, A.; Vacca, A. Hyperquad 2000; University of Leeds, Leeds, 2000.
} 


\section{Experimental details of HPLC analysis}

Analyses were performed on a Agilent 1100 HPLC system with an reversed phase column (LAB ID 70, Phenomenex Luna C18 (2) $150 \mathrm{~nm} / 4.6 / 5 \mu \mathrm{m}$ ), using $15 \mu \mathrm{L}$ as injection volume and a column temperature of $25^{\circ} \mathrm{C}$. Gradients with acetonitrile and water $(0.0059 \%$ TFA) were used for elution.

Gradient: $\quad 0 \mathrm{~min} \quad 3 \% \quad \mathrm{CH}_{3} \mathrm{CN} / \mathrm{H}_{2} \mathrm{O}[0.0059 \%$ TFA]

15 min $\quad 38 \% \quad \mathrm{CH}_{3} \mathrm{CN} / \mathrm{H}_{2} \mathrm{O}$ [0.0059\% TFA]

$20 \mathrm{~min} \quad 95 \% \quad \mathrm{CH}_{3} \mathrm{CN} / \mathrm{H}_{2} \mathrm{O}$ [0.0059\% TFA]

$25 \mathrm{~min} \quad 95 \% \quad \mathrm{CH}_{3} \mathrm{CN} / \mathrm{H}_{2} \mathrm{O}[0.0059 \% \mathrm{TFA}]$

For detection of analytes the UV absorption at 207 and $225 \mathrm{~nm}$ was used. For flavin fluorescence detection was used in addition. Acetanilide was used as tracer compound.

\section{Calculated nitrogen content via elemental analysis}

For the calculation of the maximum theoretical polymer nitrogen content for complete incorporation of the metallomonomer the following molecular weights (after template released) were used:
11-Zn-8-A and 11-Zn-8-B:
$\mathrm{M}_{\mathrm{r}}=715.9 \mathrm{~g} / \mathrm{mol} ; \mathrm{C}_{29} \mathrm{H}_{37} \mathrm{~N}_{7} \mathrm{O}_{6} \mathrm{Cl}_{2} \mathrm{Zn}_{1}$
11-Zn:
$\mathrm{M}_{\mathrm{r}}=779.9 \mathrm{~g} / \mathrm{mol} ; \mathrm{C}_{29} \mathrm{H}_{37} \mathrm{~N}_{7} \mathrm{O}_{10} \mathrm{Cl}_{2} \mathrm{Zn}_{1}$
11-Co:
$\mathrm{M}_{\mathrm{r}}=779.9 \mathrm{~g} / \mathrm{mol} ; \mathrm{C}_{29} \mathrm{H}_{37} \mathrm{~N}_{7} \mathrm{O}_{10} \mathrm{Cl}_{2} \mathrm{Co}_{1}$ 


\section{IR-Spectra of polymers}

For comparison; IR-spectra of creatinine in $\mathrm{KBr}$ :

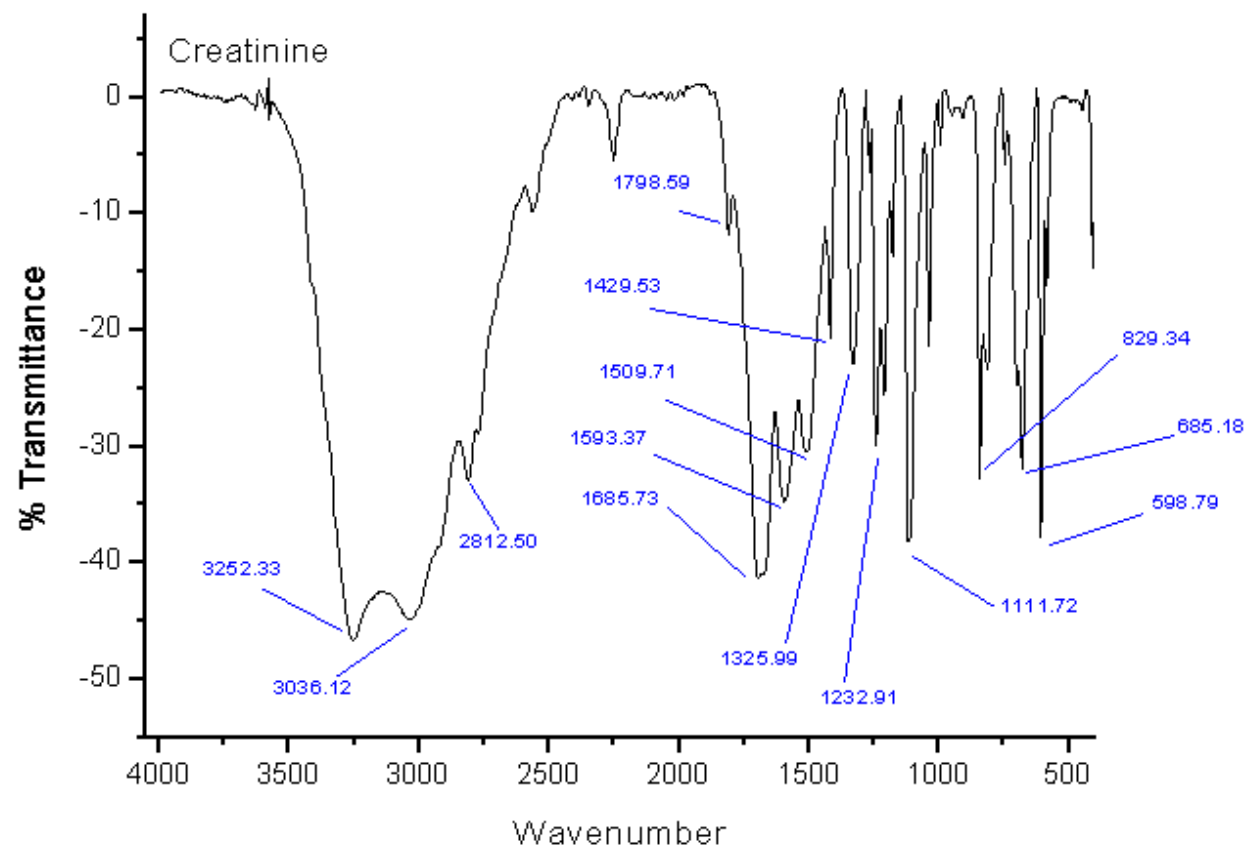

IR-spectra of polymer 11-Zn-8-A in $\mathrm{KBr}$ :

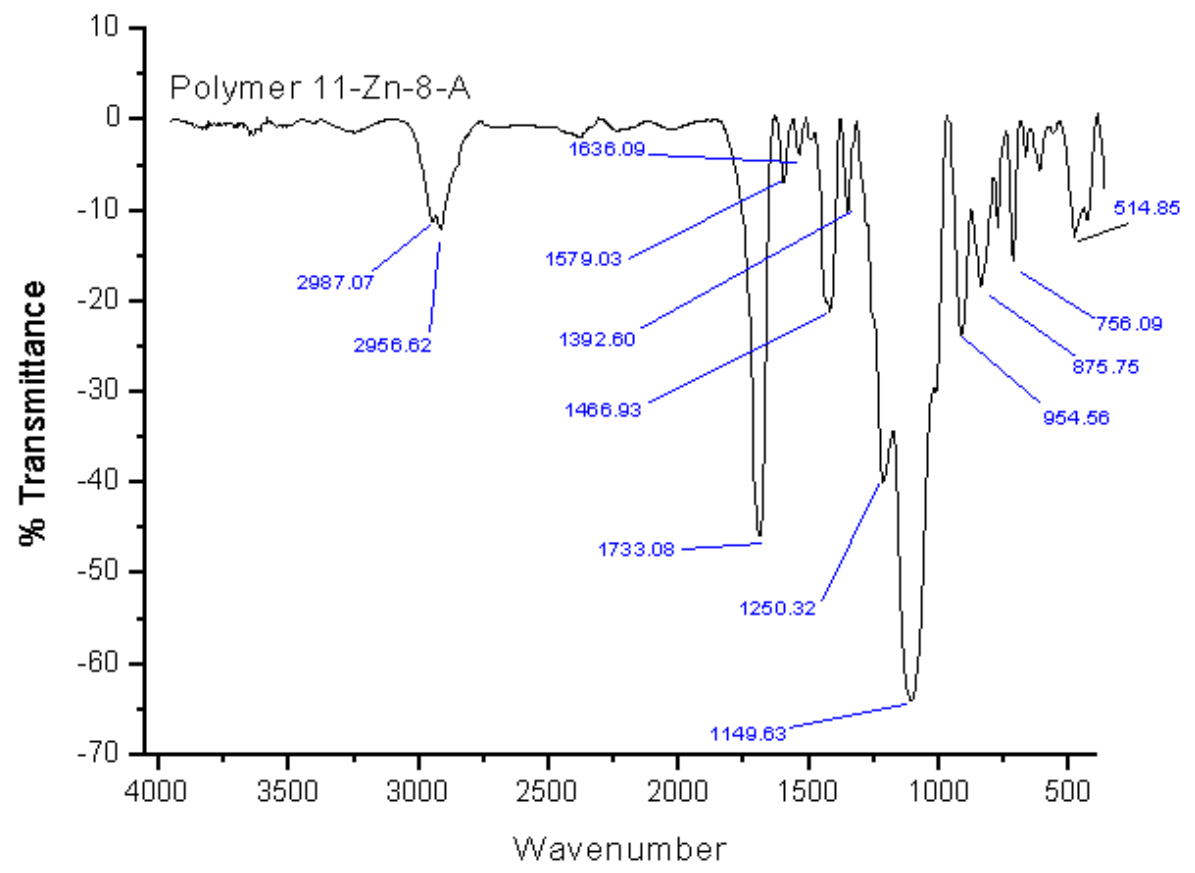


IR-spectra of polymer 11-Zn-8-B in $\mathrm{KBr}$ :

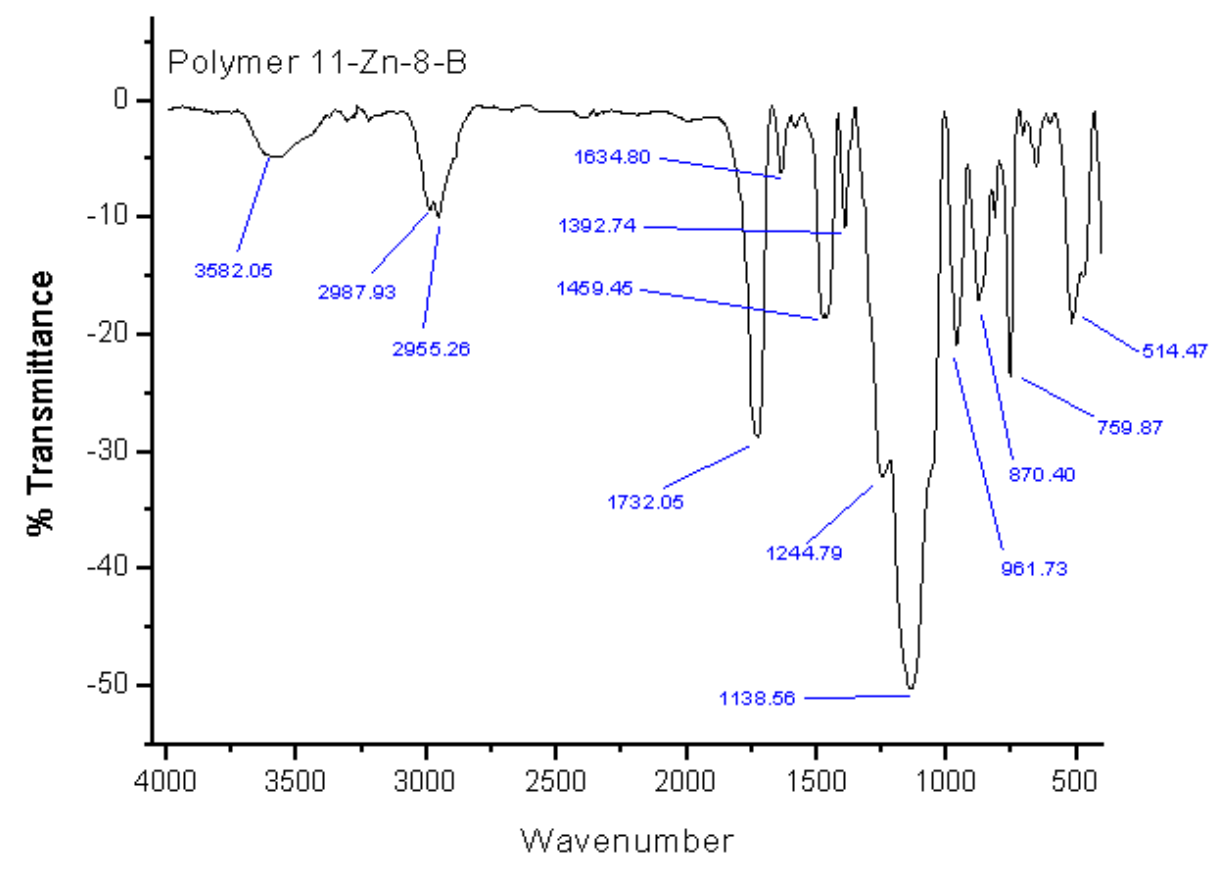

IR-spectra of polymer 11-Co in $\mathrm{KBr}$ :

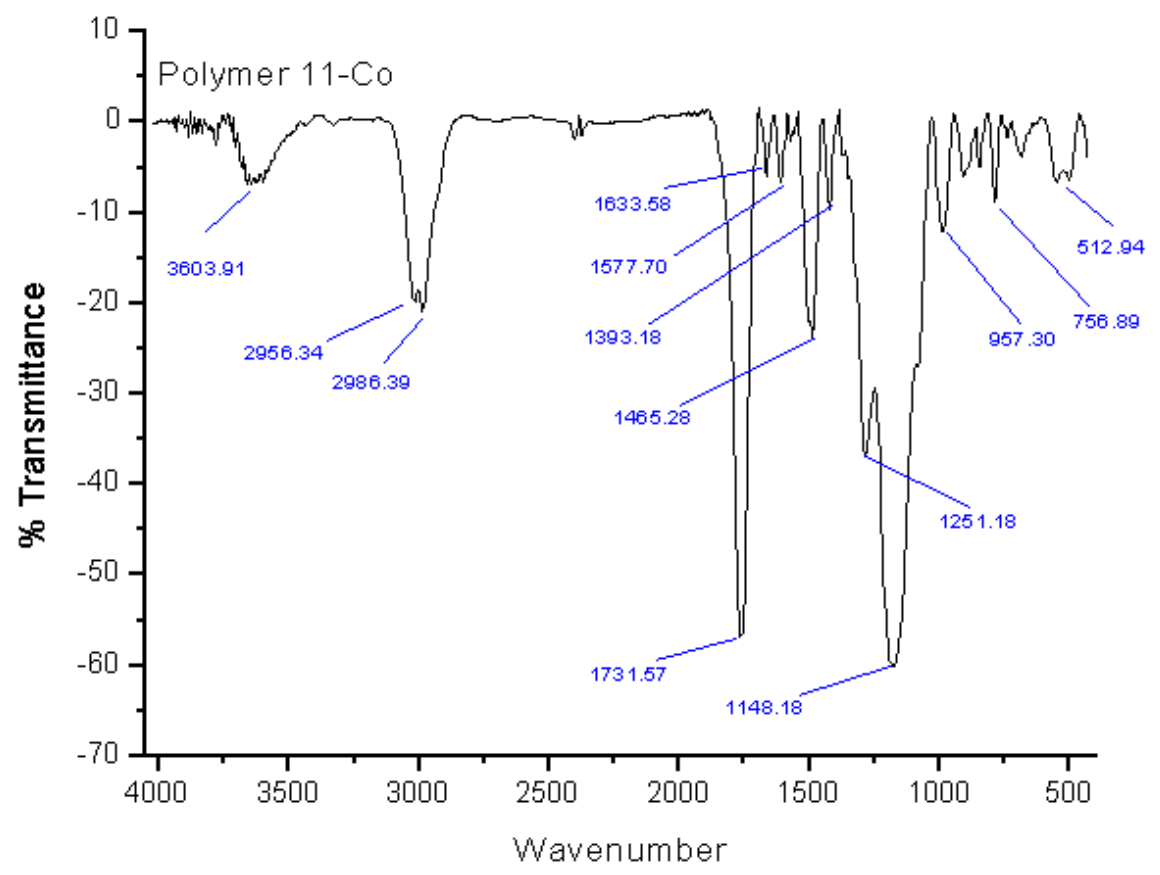


IR-spectra of polymer 11-Zn-8 in $\mathrm{KBr}$ :

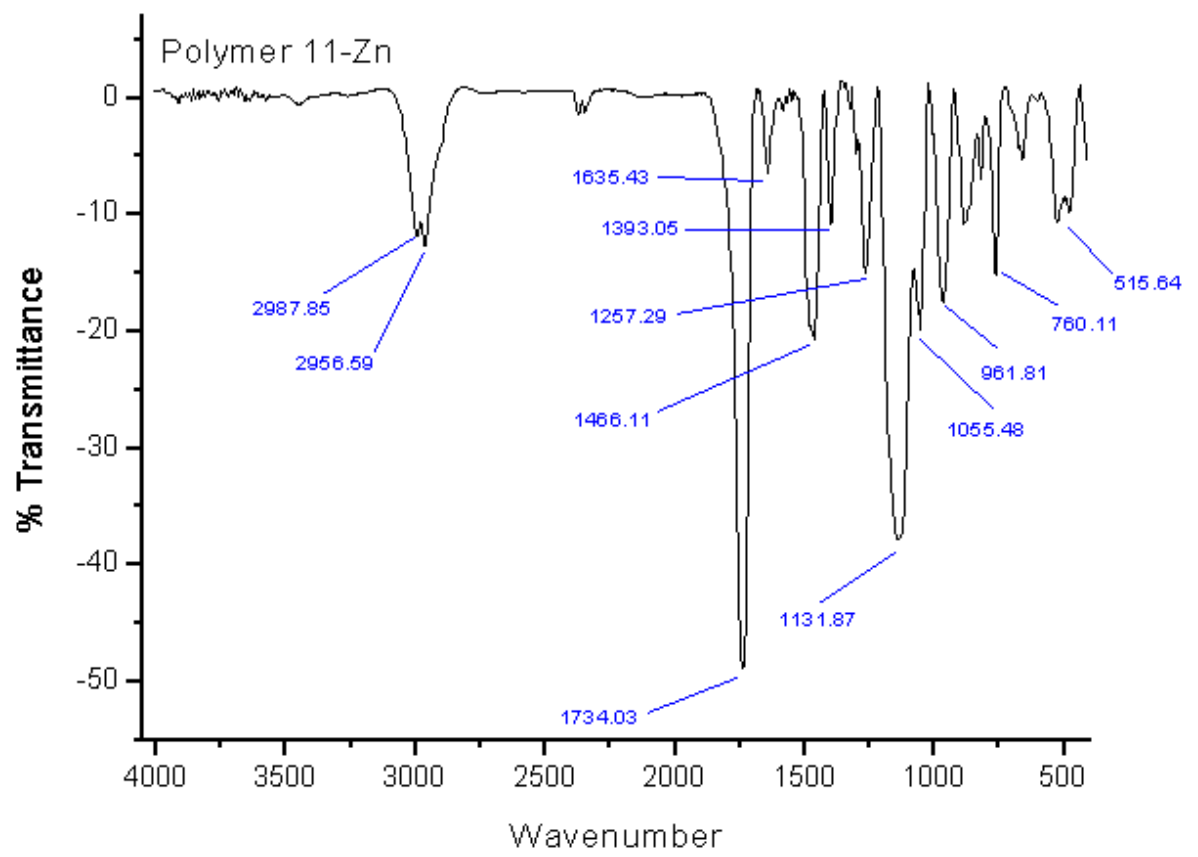




\section{UV-VIS binding experiment of tetraacetyl riboflavin to polymers 11-Zn-8-B, 11-Co and}

\section{1-blank at pH 7.1 and pH 9}

The binding experiment was performed with buffered aqueous solutions of tetraacetyl riboflavin at $\mathrm{pH} 7.1$ (Tris- $\mathrm{HCl}$ buffer; $\mathrm{c}=5.1 \times 10^{-5} \mathrm{~mol} / \mathrm{l}$ ) and $\mathrm{pH} 9.0$ (Tris-HCl buffer; $\left.\mathrm{c}=5.2 \times 10^{-5} \mathrm{~mol} / \mathrm{l}\right)$. The used amount of polymer and solution are given in table $\mathrm{S}-1$.

Polymer and solution were mixed and shaken for $12 \mathrm{~h}$ at room temperature in the darkness. The polymer was filtered off and the solution was analyzed by UV-Vis using reference solutions ( $\mathrm{pH} 7.1$ and $\mathrm{pH} 9.0$ ) that had no contact to the polymer, but were kept in buffer for the same time.

\begin{tabular}{|c|c|c|c|c|}
\hline entry & Solution & 11-Zn-8-B & 11-Co & 10-blank \\
\hline 1 & $\mathrm{pH} 7.1$ & $18 \mathrm{mg}$ and $10 \mathrm{~mL}$ & $5 \mathrm{mg}$ and $10 \mathrm{~mL}$ & $10 \mathrm{mg}$ and $10 \mathrm{~mL}$ \\
\hline 2 & $\mathrm{pH} 7.1$ & $50 \mathrm{mg}$ and $5 \mathrm{~mL}$ & - & $50 \mathrm{mg}$ and $5 \mathrm{~mL}$ \\
\hline 3 & $\mathrm{pH} 9.0$ & $18 \mathrm{mg}$ and $10 \mathrm{~mL}$ & $5 \mathrm{mg}$ and $10 \mathrm{~mL}$ & $50 \mathrm{mg}$ and $10 \mathrm{~mL}$ \\
\hline 4 & $\mathrm{pH} 9.0$ & $50 \mathrm{mg}$ and $5 \mathrm{~mL}$ & - & $50 \mathrm{mg}$ and $5 \mathrm{~mL}$ \\
\hline
\end{tabular}

Table S-1. Volume of solutions and amounts of polymer. All flavin was extracted from solution in entries 2 and 4 .

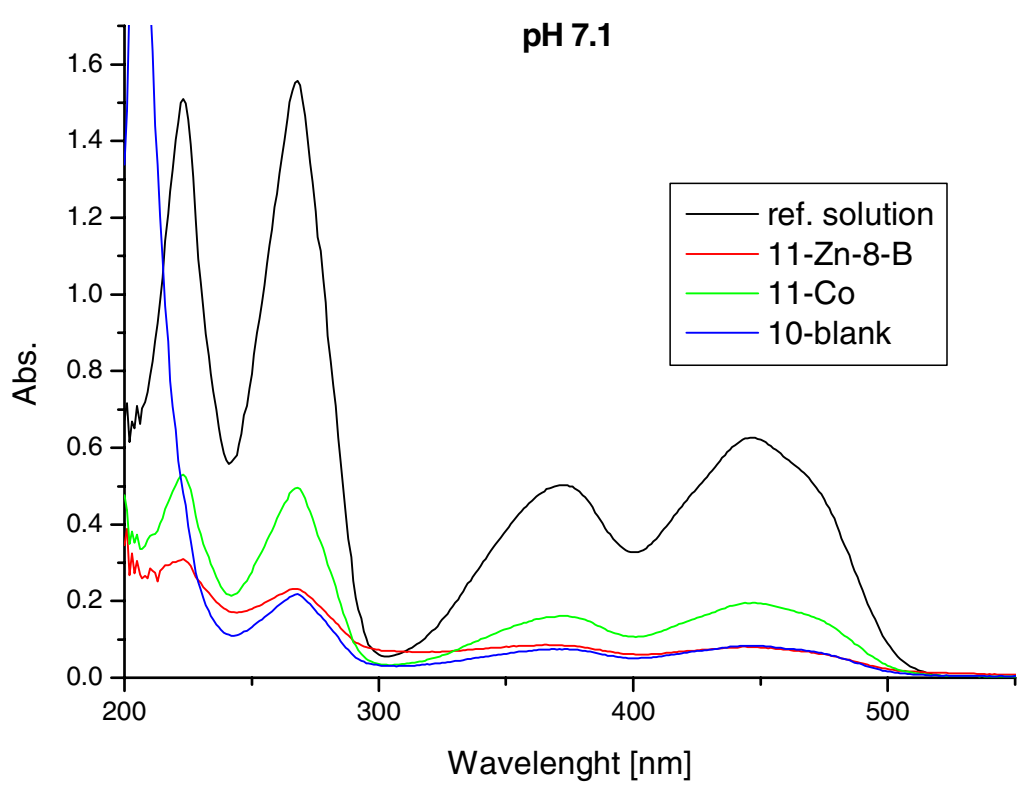

Figure S-7. UV-Vis binding experiment at $\mathrm{pH}$ 7.1. 


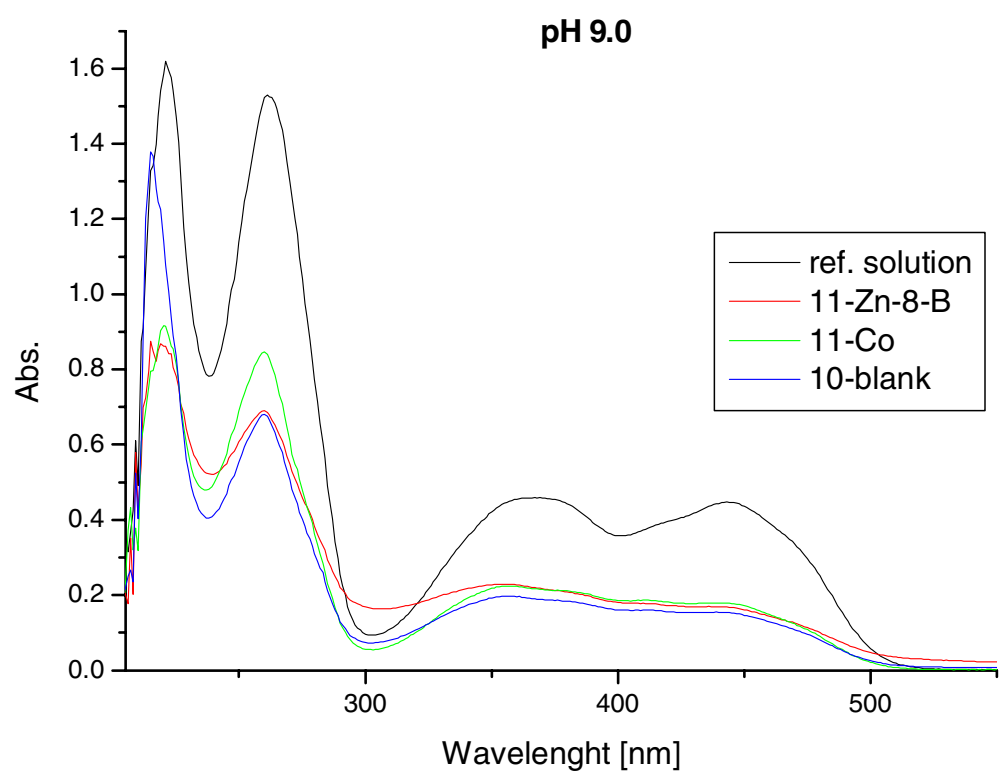

Figure S-8. UV-Vis binding experiment at $\mathrm{pH} 9.0$.

\begin{tabular}{|c|c|c|c|c|}
\hline & pH & $\begin{array}{c}\text { starting amount } \\
\text { flavin } \\
{[\mu \mathrm{mol}]}\end{array}$ & $\begin{array}{c}\text { flavin bound to } \\
\text { polymer } \\
{[\mu \mathrm{mol}]}\end{array}$ & $\begin{array}{c}\text { flavin loading of } \\
\text { polymer } \\
{[\mu \mathrm{mol} / \mathrm{g}]}\end{array}$ \\
\hline 11-Zn-8-B & 7.1 & 0.52 & 0.46 & 25.3 \\
\hline 11-Co & 7.1 & 0.52 & 0.30 & 72.0 \\
\hline 10-blank & 7.1 & 0.52 & 0.53 & 45.5 \\
\hline 11-Zn-8-B & 9.0 & 0.51 & 0.32 & 17.8 \\
\hline 11-Co & 9.0 & 0.51 & 0.31 & 61.5 \\
\hline 10-blank & 9.0 & 0.51 & 0.34 & 33.5 \\
\hline
\end{tabular}

Table S-2. Results of binding experiment with tetraacetyl riboflavin; absorption at $447 \mathrm{~nm}$ was used for quantification.

The experiments reveal an affinity of the polymeric material for flavin. Polymer 10-blank, which does not contain any metal complex binding sites, shows affinity. The binding process is therefore not related to the reversible coordination. 
The binding experiment at $\mathrm{pH} 7.1$ showed nonspecific flavin binding to the polymer surface without decomposition. At pH 9.0 nonspecific absorption and decomposition is observed; after $12 \mathrm{~h}$ in basic solution at $\mathrm{pH} 9 \sim 30 \%$ of the flavin is decomposed.

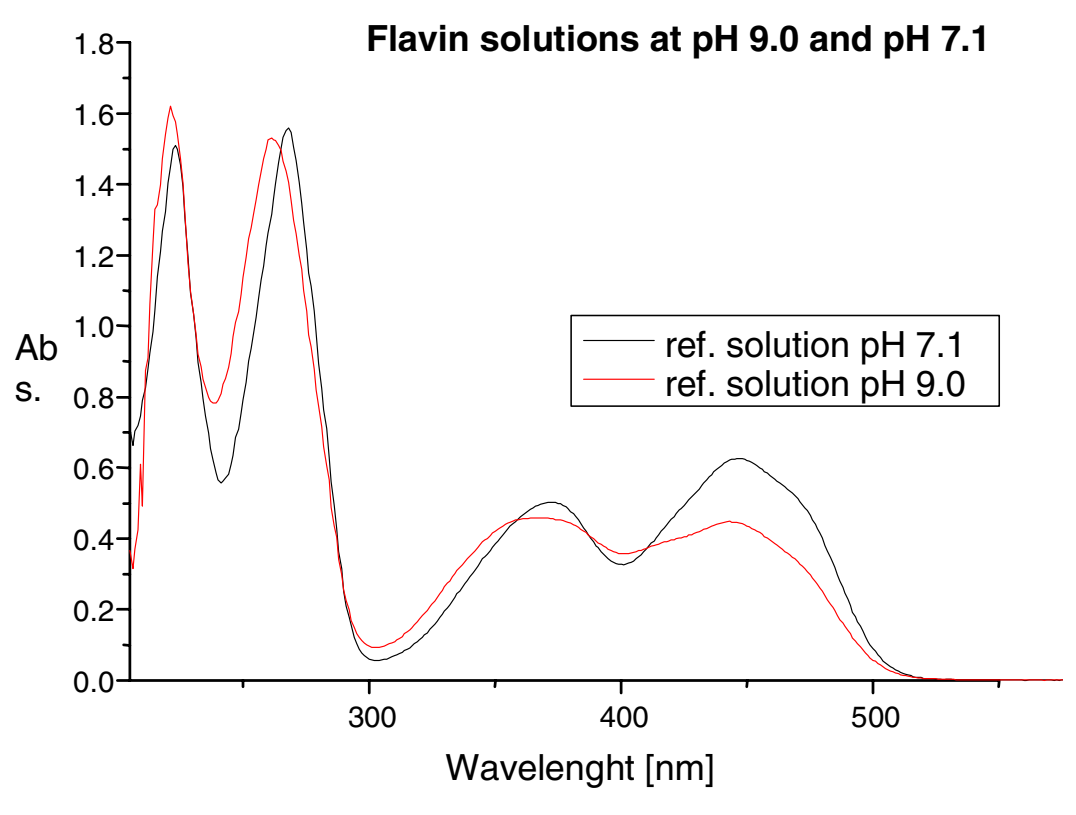

Figure S-9. Decomposition of a flavin solution at $\mathrm{pH}$ 9.0; Absorption at $447 \mathrm{~nm}$ was used for quantification. 


\section{Materials and Techniques}

Compound 1 was synthesized according to a known procedure. ${ }^{i}$ Melting points were taken on a hot-plate microscope apparatus and are not corrected. NMR spectra were recorded at 300 and $400 \mathrm{MHz}$ for $\left({ }^{1} \mathrm{H}\right)$ and 75 and $100 \mathrm{MHz}$ for $\left({ }^{13} \mathrm{C}\right)$ in [D]-chloroform solutions unless otherwise stated. The multiplicity of ${ }^{13} \mathrm{C}$ signals was determined with DEPT technique and quoted as (+) for $\mathrm{CH}_{3}$ or $\mathrm{CH}$, (-) for $\mathrm{CH}_{2}$, and $\left(\mathrm{C}_{\text {quat }}\right)$ for quaternary carbons. $\mathrm{UV}$ spectra were recorded on Varian Cary 50 Bio. IR spectra were recorded on Bio-Rad FTS 3000 MX FT-IR.. Syntheses were performed under inert atmosphere. Vinylbenzyl alcohol (4) was purchased form Acros Organics as a mixture of regioisomers (meta : para; 7:3) and was used as received. DMF was used without further purification and was degassed in the reaction tube by bubbling through nitrogen.

\section{Synthesis}

Tri-tert-butyl-10-(4,6-dichloro-[1,3,5]triazine-2-yl)-1,4,7,10-tetraaza-cyclododecane-1,4,7tricarboyxlate (3): Cyanuric chloride $(1.17 \mathrm{~g}, 6.35 \mathrm{mmol})$ and $\mathrm{K}_{2} \mathrm{CO}_{3}$ were suspended in acetone $(15 \mathrm{~mL})$, cooled to $-15{ }^{\circ} \mathrm{C}$ and a solution of tri-tert-butyl-1,4,7,10-tetraazacyclododecane-1,4,7-tricarboxylate $(3.0 \mathrm{~g}, 0.35 \mathrm{mmol})$ in acetone $(15 \mathrm{~mL})$ was added over $20 \mathrm{~min}$. The reaction mixture was stirred at $-15^{\circ} \mathrm{C}$ for $3 \mathrm{~h}$, the solvent was removed in vacuum and the residue was chromatographed on silica (EE:PE $\left.=20: 80, \mathrm{R}_{f}=0.39\right)$ to yield $\mathbf{3}$ (3.7 g, $94 \%$ ), as a colorless solid, mp $176{ }^{\circ} \mathrm{C} .-\mathrm{IR}(\mathrm{KBr}): \tilde{v}=2975 \mathrm{~cm}^{-1}, 2933,1698,1573$, 1253, 1162, 777. - UV/Vis $\left(\mathrm{CH}_{3} \mathrm{CN}\right): \lambda_{\max }(\lg \varepsilon)=248 \mathrm{~nm}(4.176) .-{ }^{1} \mathrm{H}$ NMR $(400 \mathrm{MHz}$, $\left.\mathrm{CDCl}_{3}\right): \delta=1.43\left(\mathrm{~s}, 18 \mathrm{H}, \mathrm{Boc}-\mathrm{CH}_{3}\right), 1.47\left(\mathrm{~s}, 9 \mathrm{H}, \mathrm{Boc}-\mathrm{CH}_{3}\right), 3.43-3.53\left(\mathrm{~m}, 12 \mathrm{H}, \mathrm{CH}_{2}\right), 3.73$ (bs, $\left.4 \mathrm{H}, \mathrm{CH}_{2}\right) .-{ }^{13} \mathrm{C}$ NMR $\left(100 \mathrm{MHz}, \mathrm{CDCl}_{3}\right): \delta=28.3,28.4\left(+, \mathrm{Boc}_{-} \mathrm{CH}_{3}\right), 48.9,49.7,50.3$, 51.7 (-, Cyclen- $\left.\mathrm{CH}_{2}\right), 80.3,80.6\left(\mathrm{C}_{\text {quat }}\right.$, Boc-C $), 156.1,157.6\left(\mathrm{C}_{\text {quat }}\right.$, Boc-CO $), 164.6\left(\mathrm{C}_{\text {quat }}\right.$, $\left.\mathrm{C}_{\text {Aryl }} \mathrm{N}\right), 169.9\left(\mathrm{C}_{\text {quat }}, \mathrm{C}_{\text {aryl }}-\mathrm{Cl}\right) .-\mathrm{MS}(\mathrm{ESI}) \mathrm{m} / \mathrm{z}(\%): 620(100)[\mathrm{M}+\mathrm{H}]^{+}, 642(8)[\mathrm{M}+\mathrm{Na}]^{+}$. $\mathrm{C}_{26} \mathrm{H}_{43} \mathrm{~N}_{7} \mathrm{O}_{6} \mathrm{Cl}_{2}$ (620.58): calcd. C 50.32, H 6.98, N 15.80; found C 50.41, H 7.08, N 15.67. 
Tris-Boc-cyclen-bis-hydroxymethyl-styrenyl-triazine (5): To a solution of vinylbenzyl alcohol 4 (2.63 g, $19.6 \mathrm{mmol})$ in THF $(100 \mathrm{~mL})$ was added $\mathrm{NaH}(0.75 \mathrm{~g}, 29.4 \mathrm{mmol})$ and the blue reaction mixture was stirred for $1 \mathrm{~h}$ at RT. Compound $3(3.42 \mathrm{~g}, 4.91 \mathrm{mmol})$ and $\mathrm{K}_{2} \mathrm{CO}_{3}$ ( $2.03 \mathrm{~g}, 14.7 \mathrm{mmol})$ were added and the mixture was stirred for $18 \mathrm{~h}$ at RT. The reaction mixture was filtered under nitrogen, the precipitate washed with $20 \mathrm{~mL}$ of THF and the solvent was removed in vacuum at room temp. The residue was chromatographed on silica gel $\left(\mathrm{EE}: \mathrm{PE}=50: 50, \mathrm{R}_{f}=0.35 ; \mathrm{PE}: \mathrm{EE}=70: 30\right)$ to give $3.68 \mathrm{~g}(92 \%)$ of $\mathbf{5}$ as a colorless crystalline solid, mp $134{ }^{\circ} \mathrm{C}$. - IR $(\mathrm{KBr}): \widetilde{v}=2975 \mathrm{~cm}^{-1}, 2932,1693,1535,1249,1164,817$, 778. - UV/Vis $\left(\mathrm{CH}_{3} \mathrm{CN}\right): \lambda_{\max }(\lg \varepsilon)=243 \mathrm{~nm}(4.573), 283$ (3.091), 293 (2.901). - ${ }^{1} \mathrm{H}$ NMR $\left(300 \mathrm{MHz}, \mathrm{CDCl}_{3}\right): \delta=1.35\left(\mathrm{~s}, 18 \mathrm{H}, \mathrm{Boc}-\mathrm{CH}_{3}\right), 1.47$ (s, $\left.9 \mathrm{H}, \mathrm{Boc}-\mathrm{CH}_{3}\right), 3.19-3.85(\mathrm{~m}, 16 \mathrm{H}$, $\left.\mathrm{CH}_{2}\right), 5.24\left(\mathrm{~d}, 2 \mathrm{H},{ }^{3} J_{\mathrm{Z}}=10.8 \mathrm{~Hz}, \mathrm{CH}_{2}\right.$-Z-vinyl), $5.41\left(\mathrm{~s}, 4 \mathrm{H}, \mathrm{CH}_{2}\right.$-benzyl), $5.74\left(\mathrm{~d}, 2 \mathrm{H},{ }^{3} J_{E}=\right.$ $17.8 \mathrm{~Hz}, \mathrm{CH}_{2}$-E-vinyl), 6.70 (dd, $\left.2 \mathrm{H},{ }^{3} J_{z}=10.7 \mathrm{~Hz},{ }^{3} J_{E}=17.8 \mathrm{~Hz}, \mathrm{CH}-\mathrm{Vinyl}\right), 7.21-7.52$ (m, $8 \mathrm{H}$, arene). $-{ }^{13} \mathrm{C}$ NMR $\left(75 \mathrm{MHz}, \mathrm{CDCl}_{3}\right): \delta=28.3,28.5\left(+, \mathrm{Boc}^{-\mathrm{CH}_{3}}\right), 49.4,49.9,50.1,51.5$ (-, cyclen- $\left.\mathrm{CH}_{2}\right), 68.5$ (-, benzyl- $\left.\mathrm{CH}_{2}\right), 79.9,80.3\left(\mathrm{C}_{\text {quat }}\right.$, Boc-C), 114.2 (-, vinyl- $\left.\mathrm{CH}_{2}\right), 125.8$, 126.2, 127.1, 128.6, 136.5 (+, CH-aryl und $\mathrm{CH}$-vinyl), 127.9, 137.7 ( $\mathrm{C}_{\text {quat }}$, benzene), 156.2, $157.6\left(\mathrm{C}_{\text {quat }}\right.$, Boc-CO), 167.7, $171.4\left(\mathrm{C}_{\text {quat }}\right.$ triazine $) .-\mathrm{MS}(\mathrm{ESI}) \mathrm{m} / \mathrm{z}(\%): 816(100)[\mathrm{M}+\mathrm{H}]^{+}$, $638(15)[\mathrm{M}+\mathrm{Na}]^{+} . \mathrm{C}_{44} \mathrm{H}_{61} \mathrm{~N}_{7} \mathrm{O}_{8}$ (620.58): calcd. $\mathrm{C}$ 64.75, $\mathrm{H}$ 7.54, N 12.02; found $\mathrm{C} 64.83, \mathrm{H}$ 7.59, N 12.31 .

\section{Cyclen-bis-benzhydroxystyrenyl-triazine zinc(II) bis perchlorate (6-Zn): Compound $\mathbf{5}$} (500 mg, $0.61 \mathrm{mmol})$ was dissolved in diethylether saturated with $\mathrm{HCl}(60 \mathrm{~mL})$ and the reaction mixture was stirred for $45 \mathrm{~min}$. The precipitated product was collected and dried in vacuum to yield $391 \mathrm{mg}$ (quantitative yield) of the ammonium salt $\mathbf{6}-\mathbf{N H}_{2}^{+}$as a hygroscopic colorless salt. mp: $124{ }^{\circ} \mathrm{C}$; IR $(\mathrm{KBr}): \widetilde{v}\left[\mathrm{~cm}^{-1}\right]=3445,2953,1677,1615,1337,1201,815$, 771; UV/Vis $\left(\mathrm{CH}_{3} \mathrm{CN}\right): \lambda_{\max }[\mathrm{nm}](\lg \varepsilon)=241$ (4.071), $282(2.848) ;{ }^{1} \mathrm{H}$ NMR $(400 \mathrm{MHz}$, 
DMSO-d $\left.{ }_{6}\right): \delta=2.98-3.15$ (m, $12 \mathrm{H}, \mathrm{CH}_{2}$-cyclen), $3.63-3.74$ (m, $4 \mathrm{H}, \mathrm{CH}_{2}$-cyclen), 5.24 (d, $2 \mathrm{H},{ }^{3} \mathrm{~J}=10.8 \mathrm{~Hz}, \mathrm{CH}_{2}$-Z-vinyl), 5.37 (s, $4 \mathrm{H}, \mathrm{CH}_{2}$-benzyl), 5.81 (d, $2 \mathrm{H},{ }^{3} J=17.7 \mathrm{~Hz}$, $\mathrm{CH}_{2}$-E-vinyl), 6.68 (dd, $2 \mathrm{H},{ }^{3} \mathrm{~J}=10.8 \mathrm{~Hz},{ }^{3} J_{E}=17.7 \mathrm{~Hz}, \mathrm{CH}$-vinyl), 7.19-7.48 (m, $8 \mathrm{H}, \mathrm{CH}-$ aromatic), $8.43-9.17\left(\mathrm{~m}, 6 \mathrm{H},{ }^{+} \mathrm{NH}_{2}\right) ;{ }^{13} \mathrm{C} \mathrm{NMR}\left(100 \mathrm{MHz}, \mathrm{DMSO}-\mathrm{d}_{6}\right): \delta=43.2,43.5,45.7$, 47.7 (-, $\mathrm{CH}_{2}$-cyclen), 68.2 (-, $\mathrm{CH}_{2}$-benzyl), 114.7 (-, $\mathrm{CH}_{2}$-vinyl), 126.8, 127.4, 127.5, 128.2, 128.9, 136.1 (+, CH-aromatic and CH-vinyl), 128.1, 153.2, 166.3, 170.8, ( $\mathrm{C}_{\text {quat. }}$, arene $)$; MS (ESI, MeOH): m/z (\%) = $516(100)[\mathrm{MH}]^{+}, 552(95),\left[\mathrm{MH}_{2}^{2+}+\mathrm{Cl}^{-}\right]^{+}, 588(35),\left[\mathrm{MH}_{3}^{3+}+2\right.$ $\left.\mathrm{Cl}^{-}\right]^{+}$.

A strong basic ion exchange resin was swollen for $15 \mathrm{~min}$ in a methanol/water (1:3) mixture and washed neutral with water. A column was charged with resin $(6 \mathrm{~mL}, 5.4 \mathrm{mmol}$ hydroxy equivalents at a given capacity of $0.9 \mathrm{mmol} / \mathrm{mL})$, the ammonium salt $\mathbf{6}-\mathbf{N H}_{2}^{+}(391 \mathrm{mg}, 0.61$ mmol) dissolved in water $(15 \mathrm{~mL})$ and methanol $(5 \mathrm{~mL})$ was given onto the column and eluated with the same amount of solvents. The eluate was lyophilized to yield $295 \mathrm{mg}$ (94\%) of free base 6-NH, as a colorless solid. mp: $96{ }^{\circ} \mathrm{C}$; IR $(\mathrm{KBr}): \tilde{v}\left[\mathrm{~cm}^{-1}\right]=3446,2951,1621$, 1569, 1365, 811, 769; UV/Vis $\left(\mathrm{CH}_{3} \mathrm{CN}\right): \lambda_{\max }[\mathrm{nm}](\lg \varepsilon)=242(3.962), 293(2.625) ;{ }^{1} \mathrm{H}$ NMR $\left(400 \mathrm{MHz}, \mathrm{MeOH}-\mathrm{d}_{4}\right): \delta=2.76-2.82\left(\mathrm{~m}, 8 \mathrm{H}, \mathrm{CH}_{2}\right.$-cyclen $), 3.09-3.14\left(\mathrm{~m}, 4 \mathrm{H}, \mathrm{CH}_{2}-\right.$ cyclen), 3.71 - 3.73 (m, $4 \mathrm{H}, \mathrm{CH}_{2}$-cyclen), 5.24 (d, $2 \mathrm{H},{ }^{3} \mathrm{~J}=10.6 \mathrm{~Hz}, \mathrm{CH}_{2}$-Z-vinyl), 5,43 (s, 4 $\mathrm{H}, \mathrm{CH}_{2}$-benzyl), $5.78\left(\mathrm{~d}, 2 \mathrm{H},{ }^{3} \mathrm{~J}=17.6 \mathrm{~Hz}, \mathrm{CH}_{2}\right.$-E-vinyl), $6.76\left(\mathrm{dd}, 2 \mathrm{H},{ }^{3} \mathrm{~J}=10.6 \mathrm{~Hz}\right.$, ${ }^{3} J=17.6 \mathrm{~Hz}, \mathrm{CH}$-vinyl), $7.22-7.45$ (m, $8 \mathrm{H}, \mathrm{CH}$-arene); ${ }^{13} \mathrm{C} \mathrm{NMR}\left(100 \mathrm{MHz}, \mathrm{MeOH}-\mathrm{d}_{4}\right)$ : $\delta=43.7,44.8,45.2,46.7$ (-, $\mathrm{CH}_{2}$-cyclen), 66.0 (-, $\mathrm{CH}_{2}$-benzyl), 112.1 (-, $\mathrm{CH}_{2}$-vinyl), 125.1, 126.7, 127.0, 127.9, 128.3, 134.3 (+, CH-arene and vinyl), 127.9, 152.1, 164.6, 170.5, $\left(\mathrm{C}_{\text {quat. }}\right.$ arene); $\mathrm{MS}(\mathrm{ESI}, \mathrm{MeOH}+1 \% \mathrm{AcOH}): \mathrm{m} / \mathrm{z}(\%)=516(100)[\mathrm{MH}]^{+} ; \mathrm{HRMS}$ $\left(\mathrm{C}_{29} \mathrm{H}_{37} \mathrm{~N}_{7} \mathrm{O}_{2}\right)$ : calcd. $516.3087[\mathrm{MH}]^{+}$, found $516.3079[\mathrm{MH}]^{+} \pm 1.4 \mathrm{ppm}$.

Compound 6-NH (200 mg, $0.39 \mathrm{mmol})$ was dissolved in methanol (15 mL) and zinc(II) perchlorate $(145 \mathrm{mg}, 0.39 \mathrm{mmol})$ dissolved in methanol $(5 \mathrm{~mL})$ was added with stirring. The product starts precipitating from solution after a few minutes, and the solution was stirred for 
additional $48 \mathrm{~h}$ to ensure complete reaction. The product was collected and dried in vacuum to yield $311 \mathrm{mg}$ (quantitative yield) of $\mathbf{6 - Z n}$, as a colorless solid. mp: $107^{\circ} \mathrm{C}$ (dec.); IR (KBr): $\widetilde{v}\left[\mathrm{~cm}^{-1}\right]=3441,2951,1585,1359,1092,789,695 ; \mathrm{UV} / \mathrm{Vis}\left(\mathrm{CH}_{3} \mathrm{CN}\right): \lambda_{\max }[\mathrm{nm}](\lg \varepsilon)=232$ (3.765), 280 (2.823); ${ }^{1} \mathrm{H}$ NMR (400 MHz, DMSO-d $): \delta=2.68-3.38\left(\mathrm{~m}, 17 \mathrm{H}, \mathrm{CH}_{2}\right.$-cyclen and NH), $3.71-3.77(\mathrm{~m}, 2 \mathrm{H}, \mathrm{NH}), 5.26$ (d, $2 \mathrm{H},{ }^{3} \mathrm{~J}=10.8 \mathrm{~Hz}, \mathrm{CH}_{2}$-Z-vinyl), 5.41 (s, $4 \mathrm{H}$, $\mathrm{CH}_{2}$-benzyl), $5.82\left(\mathrm{~d}, 2 \mathrm{H},{ }^{3} J=17.6 \mathrm{~Hz}, \mathrm{CH}_{2}\right.$-E-vinyl), $6.73\left(\mathrm{dd}, 2 \mathrm{H},{ }^{3} J=10.7 \mathrm{~Hz},{ }^{3} J=17.6\right.$ $\mathrm{Hz}, \mathrm{CH}$-vinyl), 7.19 - 7.51 (m, $8 \mathrm{H}, \mathrm{CH}$-arene); ${ }^{13} \mathrm{C}$ NMR (100 MHz, DMSO-d $)_{6}: \delta=44.3$, 44.9, 45.8, 53.5 (-, $\mathrm{CH}_{2}$-cyclen), 67.4 (-, $\mathrm{CH}_{2}$-benzyl), 113.4 (-, $\mathrm{CH}_{2}$-vinyl), 126.4, 126.1, 126.4, 127.9, 128.1, 134.7 (+, CH-arene and vinyl), 127.4, 152.4, 165.9, 169.8, $\left(\mathrm{C}_{\text {quat. }}\right.$ arene $)$; MS (ESI, $\left.\mathrm{CH}_{3} \mathrm{CN}\right): \mathrm{m} / \mathrm{z}(\%)=640(100)\left[\mathrm{M}^{2+}+\mathrm{CH}_{3} \mathrm{COO}^{-}\right]^{+}, 291(35)[\mathrm{M}]^{2+}$.

The complex 6-Co(II) was prepared in the same way using $\mathrm{Co}\left(\mathrm{ClO}_{4}\right)_{2}$ for complexation.

Preparation of complex 6-Zn-7: Complex 6-Zn (320 mg, $0.41 \mathrm{mmol})$ was dissolved in methanol $(60 \mathrm{~mL})$ and water $(10 \mathrm{~mL})$ under nitrogen. Tetraacetyl riboflavin $(7,224 \mathrm{mg}, 0.41$ mmol), dissolved in $20 \mathrm{~mL}$ of a mixture of $\mathrm{CH}_{2} \mathrm{Cl}_{2} /$ methanol (1:1), and aqueous sodium hydroxide solution $(33 \mathrm{mg}, 0.82 \mathrm{mmol}$ in $4 \mathrm{~mL}$ of water) were added with stirring. After 2 min a yellow precipitate formed. The reaction mixture was stirred for $3 \mathrm{~h}$ to complete reaction, the precipitate was collected by filtration and dried in vacuum. Yield: $487 \mathrm{mg}$ of 6Zn-7, as a yellow solid. Complex 6-Zn-7 has a poor solubility, therefore no NMR-data could be obtained. MS (ESI, MeOH): m/z (\%)=1123 (100) [6-Zn-7] $]^{+}$

Preparation of complex 6-Zn-8: Complex 6-Zn (699 mg, $0.89 \mathrm{mmol})$ was dissolved in methanol $(40 \mathrm{~mL})$ and water $(10 \mathrm{~mL})$ under nitrogen. Creatinine-hydrochloride $(133 \mathrm{mg}$, $0.89 \mathrm{mmol})$ and sodium hydroxide $(107 \mathrm{mg}, 2.67 \mathrm{mmol})$ in $10 \mathrm{~mL}$ of a 1:1 mixture of water and methanol were added with stirring. The reaction mixture was stirred for $30 \mathrm{~min}$ to complete reaction, the solvent was removed and the precipitate was dried in vacuum. 
Aggregate 6-Zn-8 is stable only in the presence of excess $\mathrm{NaOH}$ and contains some $\mathrm{NaCl}$. Yield: $910 \mathrm{mg}$ of 6-Zn-8, as a colorless solid. MS (ESI, MeOH): m/z (\%) = 692 (85) [6-Zn$8]^{+}$.

Preparation of polymer 10-blank: A screw capped thick wall glass tube was flushed with nitrogen and charged with $3.0 \mathrm{~g}(15.1 \mathrm{mmol})$ of ethyleneglycol dimethylacrylate (EDGMA), AIBN (24.8 mg, $0.15 \mathrm{mmol})$ and $10 \mathrm{~mL}$ of DMF. A stream of nitrogen was bubbled through the reaction mixture for $5 \mathrm{~min}$, then the tube was sealed and heated to $60^{\circ} \mathrm{C}$ for $24 \mathrm{~h}$. After cooling to room temperature the obtained copolymer was grained, washed with water $(3 \times 40$ $\mathrm{mL})$, methanol, (3 x $40 \mathrm{~mL})$ and was extracted with water/methanol (20:80) for $24 \mathrm{~h}$ in a Soxlet apparatus. After drying in high vacuum the colorless copolymer was grained in a bullet mill for 2-3 min to give a fine powder $(2.72 \mathrm{~g})$.

Preparation of polymer 11-Zn: A screw capped thick wall glass tube was flushed with nitrogen and charged with complex $\mathbf{6 - Z n}(310 \mathrm{mg}, 0.4 \mathrm{mmol})$, ethyleneglycol dimethylacrylate $(1997 \mathrm{mg}, 10.1 \mathrm{mmol})$, AIBN (12.9 mg, $79 \mu \mathrm{mol})$ and $6 \mathrm{~mL}$ of DMF. A stream of nitrogen was bubbled through the reaction mixture for $5 \mathrm{~min}$, then the tube was sealed and heated to $60^{\circ} \mathrm{C}$ for $22 \mathrm{~h}$. After cooling to room temperature the obtained copolymer was grained, washed with water $(3 \times 20 \mathrm{~mL})$, methanol $(3 \times 20 \mathrm{~mL})$ and was extracted with water/methanol (20:80) for $24 \mathrm{~h}$ in a Soxlet apparatus. After drying in high vacuum the colorless copolymer was grained in a bullet mill for 2-3 min to give a fine powder (1.97 g).

Preparation of polymer 11-Co: A screw capped thick wall glass tube was flushed with nitrogen and charged with complex 6-Co $(380 \mathrm{mg}, 0.49 \mathrm{mmol})$, ethyleneglycol dimethylacrylate $(2280 \mathrm{mg}, 11.5 \mathrm{mmol})$, AIBN (15.9 mg, $97 \mu \mathrm{mol})$ and $7 \mathrm{~mL}$ of DMF. A stream of nitrogen was bubbled through the reaction mixture for $5 \mathrm{~min}$, then the tube was 
sealed and heated to $60^{\circ} \mathrm{C}$ for $22 \mathrm{~h}$. After cooling to room temperature the obtained copolymer was grained, washed with water $(3 \times 40 \mathrm{~mL})$, methanol $(3 \times 40 \mathrm{~mL})$ and was extracted with water/methanol (20:80) for $24 \mathrm{~h}$ in a Soxlet apparatus. After drying in high vacuum the lightly pink copolymer was grained in a bullet mill for 2-3 min to give a fine powder $(2.17 \mathrm{~g})$.

Preparation of polymer 11-Zn-8-A: A screw capped thick wall glass tube was flushed with nitrogen and charged with complex 6-Zn-8 (450 mg, $0.44 \mathrm{mmol})$, ethyleneglycol dimethylacrylate $(2130 \mathrm{mg}, 10.74 \mathrm{mmol}), \operatorname{AIBN}(14.8 \mathrm{mg}, 90 \mu \mathrm{mol})$ and $5 \mathrm{~mL}$ of DMF. Aggregate 6-Zn-8 is stable only in the presence of excess $\mathrm{NaOH}$ and contains $\mathrm{NaCl}$. The amount of 6-Zn-8 is derived from 6-Zn used for its preparation. A stream of nitrogen was bubbled through the reaction mixture for $5 \mathrm{~min}$. then the tube was sealed and heated to $60^{\circ} \mathrm{C}$ for $22 \mathrm{~h}$. After cooling to room temperature the obtained polymer was grained, washed with $1 \mathrm{~N} \mathrm{HCl}(3 \times 25 \mathrm{~mL})$ to remove all creatinine, extracted with water/methanol (20:80) for $24 \mathrm{~h}$ in a Soxlet apparatus and dried in high vacuum. After drying the colorless copolymer was grained in a bullet mill for 2-3 min to give a fine powder (1.96 g).

Preparation of polymer 11-Zn-8-B: A screw capped thick wall glass tube was flushed with nitrogen and charged with complex 6-Zn-8 (300 mg, $0.29 \mathrm{mmol}$ ), ethyleneglycol dimethylacrylate $(1590 \mathrm{mg}, 8.02 \mathrm{mmol})$, AIBN $(9.5 \mathrm{mg}, 60 \mu \mathrm{mol})$ and $7 \mathrm{~mL}$ of DMF. Aggregate 6- $\mathbf{Z n - 8}$ is stable only in the presence of excess $\mathrm{NaOH}$ and contains $\mathrm{NaCl}$. The mmol amount of 6-Zn-8 corresponds to $\mathbf{6 - Z n}$ used for its preparation. A stream of nitrogen was bubbled through the reaction mixture for $5 \mathrm{~min}$, then the tube was sealed and heated to $60^{\circ} \mathrm{C}$ for $22 \mathrm{~h}$. After cooling to room temperature the obtained polymer was grained, washed with $1 \mathrm{~N} \mathrm{HCl}(3 \times 15 \mathrm{~mL})$ to remove all creatinine, extracted with water/methanol (20:80) for $24 \mathrm{~h}$ in a Soxlet apparatus and dried in high vacuum. After drying the colorless copolymer was grained in a bullet mill for 2-3 min to give a fine powder $(1.29 \mathrm{~g})$. 


\section{Binding Studies}

To determine the binding ability of the polymers to creatinine, thymine and tetraacetyl riboflavin the respective polymer $(20-250 \mathrm{mg})$ was shaken in buffered aqueous solutions $\left(\mathrm{c}=5 \times 10^{-4} \mathrm{~mol} / \mathrm{L}\right.$; Tris $/ \mathrm{HCl} \mathrm{pH}$ 9) of thymine, creatinine, tetraacetyl riboflavin or a thymine/ creatinine mixture at room temperature for $12 \mathrm{~h}$. The polymer was filtered off, washed and bound analytes were released by treatment with $50 \mathrm{~mL}$ of aqueous acetate buffer solution at $\mathrm{pH} 3.3$ for $2 \mathrm{~h}$ and subsequent acidification of the solution to $\mathrm{pH} 2$ by $1 \mathrm{~N} \mathrm{HCl}$. The concentration of free and bound analytes in the respective solutions were determined by an HPLC assay and tracer technique.

Batch and rebinding studies for 11-Zn-8-A and 11-Zn-8-B: $70 \mathrm{mg}$ of the polymer were shaken in $50 \mathrm{~mL}$ of buffered aqueous solutions of thymine or creatinine $\left(\mathrm{c}=5 \times 10^{-4} \mathrm{~mol} / \mathrm{L}\right.$; Tris/ $\mathrm{HCl} \mathrm{pH} 9$ ) at room temperature for $12 \mathrm{~h}$. The polymer was filtered off and washed with $20 \mathrm{~mL}$ Tris/ $\mathrm{HCl}$ buffer $(\mathrm{pH}$ 9) by shaking for $2 \mathrm{~h}$. The amount of bound analytes were calculated as the difference of the original amount of analytes and the remaining amount of free analytes in solution. Analyses of solution used for washing showed no analytes. For release the analytes from the polymer, it was treated with $50 \mathrm{~mL}$ of aqueous acetate buffer at $\mathrm{pH} 3.3$ for $2 \mathrm{~h}$ and was subsequently acidified with $1 \mathrm{~N} \mathrm{HCl}$ to $\mathrm{pH} 2$; shaking for $30 \mathrm{~min}$. The polymer was filtered off and the resulting solution was analyzed. Before rebinding experiments, the polymer was washed with $20 \mathrm{~mL}$ Tris/HCl buffer (pH 9) for $1 \mathrm{~h}$.

Binding studies for 11-Zn-8-A and 11-Co with tetraacetyl riboflavin: $20 \mathrm{mg}$ of polymer 11Zn-8-A was treated with $55 \mathrm{~mL}$ buffered aqueous solution of tetraacetyl riboflavin $\left(\mathrm{c}=5 \times 10^{-5} \mathrm{~mol} / \mathrm{L}\right.$; Tris $\left./ \mathrm{HCl} \mathrm{pH} 9\right)$ and $30 \mathrm{mg}$ of polymer 11-Co was treated with $70 \mathrm{~mL}$ of buffered aqueous solution of tetraacetyl riboflavin $\left(\mathrm{c}=5 \times 10^{-5} \mathrm{~mol} / \mathrm{L}\right.$; Tris $\left./ \mathrm{HCl} \mathrm{pH} 9\right)$ in the darkness for $12 \mathrm{~h}$. The polymer were filtered off and washed with $20 \mathrm{~mL}$ of Tris/ $\mathrm{HCl}$ buffer 
(pH 9) by shaking for $2 \mathrm{~h}$. The solutions were analyzed. The bound amount of analytes was calculated as the difference of the starting amount of analytes and the remaining amount of free analytes in solution. Analyses of the washing solution showed no analytes. Attempts to remove the flavin from the polymer using the described conditions for release failed.

Competitive binding and rebinding studies for 11-Zn-8-A with thymine and creatinine: $70 \mathrm{mg}$ of the polymer was shaken in $25 \mathrm{~mL}$ of buffered aqueous solutions of thymine and $25 \mathrm{~mL}$ of creatinine $\left(\mathrm{c}=5 \times 10^{-4} \mathrm{~mol} / \mathrm{L}\right.$; Tris/ $\mathrm{HCl} \mathrm{pH} \mathrm{9)}$ at room temperature for $12 \mathrm{~h}$. The polymer was filtered off and washed with $20 \mathrm{~mL}$ of Tris/HCl buffer $(\mathrm{pH} 9)$ by shaking for $2 \mathrm{~h}$. The bound amount of analytes was calculated as the difference of the starting amount of analytes and the remaining amount of free analytes in solution. Analyses of the washing solution showed no analytes. Release and rebinding of analytes are performed as described above.

Binding isotherms: Polymer 11-Zn-8-B was used for measuring the binding isotherms for thymine and creatinine. Respectively $30 \mathrm{mg}$ of the polymer and $21.5 \mathrm{~mL}$ of an aqueous buffered solution (Tris/HCl buffer $\mathrm{pH}$ 9) of creatinine and thymine were used for this experiment and the solutions were incubated with the polymer for $12 \mathrm{~h}$. The concentration of analytes is varied from $\mathrm{c}=1 \times 10^{-3} \mathrm{~mol} / \mathrm{L}$ to $\mathrm{c}=1 \times 10^{-6} \mathrm{~mol} / \mathrm{L}$. For concentrations larger than $10^{-4} \mathrm{~mol} / \mathrm{L}$, the amount of bound analytes is measured as the difference between starting concentration and non bound substrate. For concentrations smaller than $10^{-4} \mathrm{~mol} / \mathrm{L}$, the amount of bound analytes is measured after release from the polymer.

Zinc(II)-reloading experiment with 11-Zn-8-B: $250 \mathrm{mg}$ of polymer 11-Zn-8-B and $\mathrm{Zn}\left(\mathrm{ClO}_{4}\right)_{2} \cdot 6 \mathrm{H}_{2} \mathrm{O}(200 \mathrm{mg}, 0.54 \mathrm{mmol})$ are suspended in $20 \mathrm{~mL}$ of Tris/HCl buffer $(\mathrm{pH} 9)$ and $10 \mathrm{~mL}$ of $\mathrm{MeOH}$. The mixture was refluxed for $14 \mathrm{~h}$ without stirring. After cooling to room 
temperature the polymer was filtered off, washed with $20 \mathrm{~mL} \mathrm{MeOH}$ and dried in vacuum. $242 \mathrm{mg}$ of polymer 11-Zn-8-B were obtained.

$70 \mathrm{mg}$ of 11-Zn-8-B were shaken with $50 \mathrm{~mL}$ of an aqueous buffered solution (Tris/HCl buffer $\mathrm{pH} 9$ ) of creatinine for $12 \mathrm{~h}$. The polymer was filtered off and the amount of bound creatinine was calculated from the difference of the starting and the non bound amount of the analyte.

Competitive binding of polymer 11-Zn with thymine and creatinine: $76 \mathrm{mg}$ of the polymer were shaken in $25 \mathrm{~mL}$ of buffered aqueous solutions of thymine and $25 \mathrm{~mL}$ of creatinine (c $=5 \times 10^{-4} \mathrm{~mol} / \mathrm{L}$; Tris-HCl $\mathrm{pH} 9$ for both solutions) at room temperature for $12 \mathrm{~h}$. Binding and release were performed as described above. Due to the small amount of bound creatinine the solution was lyophilized after release to enhance the accuracy of analytical determination. The resulting solid was dissolved in $3 \mathrm{~mL}$ of water and the amount of bound analytes was determined by HPLC.

\footnotetext{
${ }^{i}$ Brandes, M.; Gros, C.; Denat, F.; Grilaud, R. Bull. Chem. Soc. Chim. Fr. 1996, 133, 30683076.
} 